\title{
Inhibition of IRE1 $\alpha$-driven pro-survival pathways is a promising therapeutic application in acute myeloid leukemia
}

\author{
Haibo Sun ${ }^{1,2, *}$, De-Chen Lin ${ }^{1, *}$, Xiao Guo ${ }^{1, *}$, Behzad Kharabi Masouleh ${ }^{3}$, Sigal Gery ${ }^{1}$, \\ Qi Cao ${ }^{1}$, Serhan Alkan ${ }^{1}$, Takayuki Ikezoe ${ }^{4}$, Chie Akiba ${ }^{1}$, Ronald Paquette ${ }^{5}$, Wenwen \\ Chien ${ }^{6}$, Carsten Müller-Tidow ${ }^{7}$, Yang Jing ${ }^{4}$, Konstantin Agelopoulos ${ }^{8}$, Markus \\ Müschen ${ }^{9}$, H. Phillip Koeffler ${ }^{1,6}$ \\ ${ }^{1}$ Department of Hematology and Oncology, Cedars-Sinai Medical Center, Los Angeles, CA, USA \\ ${ }^{2}$ Department of Surgery, University of California San Francisco, San Francisco, CA, USA \\ ${ }^{3}$ Department of Oncology, Hematology and Stem Cell Transplantation, RWTH Aachen University Medical School, Aachen, \\ Germany \\ ${ }^{4}$ Department of Hematology and Respiratory Medicine, Kochi University, Nankoku, Kochi, Japan \\ ${ }^{5}$ Department of Medicine, University of California at Los Angeles, Los Angeles, CA, USA \\ ${ }^{6}$ Cancer Science Institute of Singapore, National University of Singapore, Singapore \\ ${ }^{7}$ Department of Hematology and Oncology, University Hospital Halle, Halle, Germany \\ ${ }^{8}$ Department of Medicine, Hematology and Oncology, University of Muenster, Muenster, Germany \\ ${ }^{9}$ Department of Laboratory Medicine, University of California San Francisco, San Francisco, CA, USA \\ *These authors have contributed equally to this work \\ Correspondence to: Haibo Sun, e-mail: Haibo.Sun@ucsf.edu \\ De-chen Lin, e-mail: De-chen.Lin@cshs.org \\ Keywords: IRE 1, ER stress, XBPI, unfolded protein response, micro RNA
}

Received: July 13, $2015 \quad$ Accepted: January 29, $2016 \quad$ Published: February 25, 2016

\section{ABSTRACT}

Survival of cancer cells relies on the unfolded protein response (UPR) to resist stress triggered by the accumulation of misfolded proteins within the endoplasmic reticulum (ER). The IRE1 $\alpha$-XBP1 pathway, a key branch of the UPR, is activated in many cancers. Here, we show that the expression of both mature and spliced forms of XBP1 (XBP1s) is up-regulated in acute myeloid leukemia (AML) cell lines and AML patient samples. IRE1 $\alpha$ RNase inhibitors [MKC-3946, 2-hydroxy-1-naphthaldehyde (HNA), STF-083010 and toyocamycin] blocked XBP1 mRNA splicing and exhibited cytotoxicity against AML cells. IRE $1 \alpha$ inhibition induced caspase-dependent apoptosis and G1 cell cycle arrest at least partially by regulation of Bcl-2 family proteins, $\mathbf{G 1}$ phase controlling proteins (p21 ${ }^{\mathrm{cip} 1}, \mathrm{p2}^{\mathrm{kip} 1}$ and cyclin D1), as well as chaperone proteins. Xbp1 deleted murine bone marrow cells were resistant to growth inhibition by IRE1 $\alpha$ inhibitors. Combination of HNA with either bortezomib or $\mathrm{AS}_{2} \mathrm{O}_{3}$ was synergistic in AML cytotoxicity associated with induction of $\mathrm{p}-\mathrm{JNK}$ and reduction of $\mathrm{p}$-PI3K and p-MAPK. Inhibition of IRE1 $\alpha$ RNase activity increased expression of many miRs in AML cells including miR-34a. Inhibition of miR-34a conferred cellular resistance to HNA. Our results strongly suggest that targeting IRE1 $\alpha$ driven pro-survival pathways represent an exciting therapeutic approach for the treatment of AML.

\section{INTRODUCTION}

Acute myeloid leukemia (AML) is an aggressive hematological malignancy characterized by a small population of self-renewing leukemic stem cells (LSCs) giving rise to a large population of immature leukemic blasts [1-4]. LSCs are relatively insensitive to current therapies [3]. Many AML cells initially respond to treatment; however, relapse is often caused by LSCs that are intrinsically resistant to chemotherapy [5-7]. 
The overall long-term survival of AML patients remains extremely disappointing at approximately $30 \%$ to $50 \%[1$, $8,9]$. Novel therapeutic approaches are clearly needed.

Hematopoietic cells, including LSCs, are exposed to low levels of oxygen in the bone marrow, which may cause accumulation of misfolded proteins in the endoplasmic reticulum (ER), thereby stimulating ER stress and activating the unfolded-protein-response (UPR) pathway [5, 6, 10-12]. ER stress and its UPR are properly compensated in normal marrow hematopoietic cells $[13,14]$. In contrast, leukemic cells proliferating in a hostile environment of low oxygen and limited nutrients accumulate misfolded proteins in the ER, causing continuous ER stress with initiation of UPR $[15,16]$. Furthermore, leukemic cells produce mutant proteins at a high rate resulting in misfolded proteins [17]. Sustained UPR initiates cellular defense mechanisms rescuing leukemic cells from extreme cellular stress by limiting de novo entry of proteins into the ER which in turn enhances both protein folding capacity and degradation activity [16]. The ability of leukemic cells to handle ER stress may allow them to escape apoptosis and continue their growth $[16,18]$.

Inositol-requiring enzyme 1 alpha (IRE1 $\alpha$ ) is one of major ER transmembrane sensors that activates the UPR [19]. IRE1 $\alpha$ is evolutionarily conserved in eukaryotes [19]. It has both $\mathrm{Ser} / \mathrm{Thr}$ protein kinase, as well as endoribonuclease (RNase) activities. Upon activation, IRE1 $\alpha$ initiates an unconventional removal of a 26 base intron from the $\mathrm{x}$-box binding protein 1 (XBP1) mRNA, producing an active transcription factor (XBP1s). XBP1s stimulates synthesis of several UPR target genes including ER chaperones, Endoplasmic-ReticulumAssociated protein Degradation (ERAD) components and transcription factors which function to relieve protein misfolding $[19,20]$. However, IRE1 $\alpha$ acts as a doubleedged sword. If restoring ER homeostasis fails, IRE1 $\alpha$ represses adaptive responses and initiates apoptosis through Regulated IRE1-Dependent Decay (RIDD) of a large list of substrates which may eventually induces cell death[19, 20]. Caspase-2 (CASP2) is a pro-apoptotic protease required to mediate cellular apoptosis [21]. Upregulation of CASP2 initiates the intrinsic pathway of apoptosis. During RIDD, IRE1 $\alpha$ cleaves and inactivates anti-Casp2 pre-miRNAs (miR-17, miR-34a, miR-96, and miR-125b) resulting in up-regulation of CASP2. Elevated expression of CASP2 helps initiate apoptosis through activating $\mathrm{Bid}$, which causes release of mitochondrial cytochrome $\mathrm{c}$ into the cytoplasm [22, 23]. TXNIP is another direct target of miR-17 [24, 25]. TXNIP regulates ER stress-related apoptosis. RIDD increases TXNIP expression through decay of miR-17 [21-23].

The functions of the ER and its associated stress pathways in AML have been studied including recent studies that found approximately $25 \%$ of AML samples had detectable $X B P 1 s$, indicating activation of UPR and an increase of chaperone proteins [26, 27]. Many studies have reported that perturbing the UPR with proteasome inhibitors, such as bortezomib, can enhance apoptosis of AML cells [28-32]. In this study, we explored whether AML cells have activated IRE1 $\alpha$ which can be therapeutically targeted.

\section{RESULTS}

\section{XBP1 and XBP1s are up-regulated in AML}

IRE1 signaling pathway through XBP1 and $\mathrm{XBP} 1 \mathrm{~s}$ is strongly linked with ER stress and UPR [33]. To examine if XBP1 has a crucial role in AML, we first analyzed the AML methylation database (27k Illumina methylation version) from TCGA. Compared with normal samples, XBP1 was highly hypomethylated on its $\mathrm{CpG}$ island in AML cases (Figure 1A). Consistent with the methylation status, XBP1 expression was significantly up-regulated in AML cases [5 previously published microarray databases (Figure 1B) and our QRT-PCR results (Figure 1C)]. A combination analysis of the 5 published databases showed that XBP1 ranked No. 679th of the most highly expressed genes in AML (Figure 1B). Results were calculated by online analysis engine Oncomine (https://www.oncomine. org/resource/login.html). Interestingly, XBP1s was detectable in $85 \%$ (22 of 26) of the leukemia cell lines and $71 \%$ (17 of 24) of AML patient samples (Figures $1 \mathrm{D}, 1 \mathrm{E})$. Normal purified CD34+ myeloid stem cells did not have detectable XBP1s (Figure 1E). XBP1s was also significantly elevated in AML samples from patients compared to CD34+ normal myeloid stem cells ( $\mathrm{p}=0.0043, \mathrm{n}=28$ ) as measured by QRT-PCR (Figure 1F). To investigate correlations between XBP1 expression and AML clinical features, we first performed statistical analysis to correlate the expression of $X B P 1 / X B P 1 S$ with French-American-British (FAB) subtypes in our own dataset (Table S2 and Figure 1C, 1E, 1F). However, probably due to the limited numbers of cases, we did not observe a significant association between XBP1/ $X B P 1 s$ and FAB subtypes among the 24 AML samples (data not shown). We next performed similar statistical analysis using TCGA AML dataset. Since $X B P 1 s$ was not discernable from total $X B P 1$ in the dataset, we only tested total $X B P 1$ level. Interestingly, $X B P 1$ expression was significantly increased in FAB M3 subgroup compared with M0, M1 and M2 but significantly decreased in M4M7 subgroup (Figure S1). The biological significance of these correlations requires further investigations.

\section{IRE1 $\alpha$ RNase inhibitors blocked splicing of XBP1 mRNA and exhibited cytotoxicity against AML cells}

Recently, a novel small-molecule RNase inhibitor of IRE1 (MKC-3946) was noted to have potent anti- 
proliferative activity in multiple myeloma (MM) [34]. The compound was found to be very unstable in vitro; however, one of the two major hydrolyzed precursors, A-106 (2-hydroxy-1-naphthaldehyde, HNA) retained the IRE1 $\alpha$ RNase inhibitory activity [35]. Tunicamycin (TM) induces ER stress and $X B P 1$ splicing in many cells [36]. Following TM treatment, increased expression of $X B P 1 \mathrm{~s}$ mRNA and decreased XBPI $u$ (unspliced, transcriptional inactive form of XBP1) were observed in 293T and K562 myeloid leukemia cells (Figure S2A). Compared with MKC-3946, HNA showed either the same or more potent ability to inhibit the activity of IRE1 $\alpha$ to cleave XBP1 into the active XBP1s after TM induced activation of NB4 cells (Figure S2B). STF-083010 is a newly developed IRE $1 \alpha$ endonuclease specific inhibitor which has shown cytotoxic activity against human multiple myeloma [37, 38]. Treatment of AML cells with increasing drug dosage showed slightly enhanced potency of HNA compared to STF-083010 (Figures S3A-D). HNA dose-dependently inhibited XBP1s expression induced by TM in AML cell lines and AML patient samples (Figures 2A- 2C). HNA significantly decreased cellular viability of both AML cell lines (mean $\mathrm{GI}_{50}=31 \mu \mathrm{M}, \mathrm{n}=8$ ) and AML patient samples (mean $\mathrm{GI}_{50}=35 \mu \mathrm{M}, \mathrm{n}=18$ ) compared to untreated patient samples (mean $\mathrm{GI}_{50}=154 \mu \mathrm{M}, \mathrm{n}=5$, Figures 2C-2E). Importantly, HNA caused a significant inhibition (mean $\left.\mathrm{GI}_{50}=6 \mu \mathrm{M}, \mathrm{n}=6\right)$ of clonogenic growth in soft agar of AML cells from patients (Figure $2 \mathrm{~F}$ ). In contrast, HNA had very low toxicity against normal human marrow mononuclear cells (mean $\mathrm{GI}_{50}=123 \mu \mathrm{M}, \mathrm{n}=4$ ) (Figure 2E). We conducted western blotting assay on BALL1,
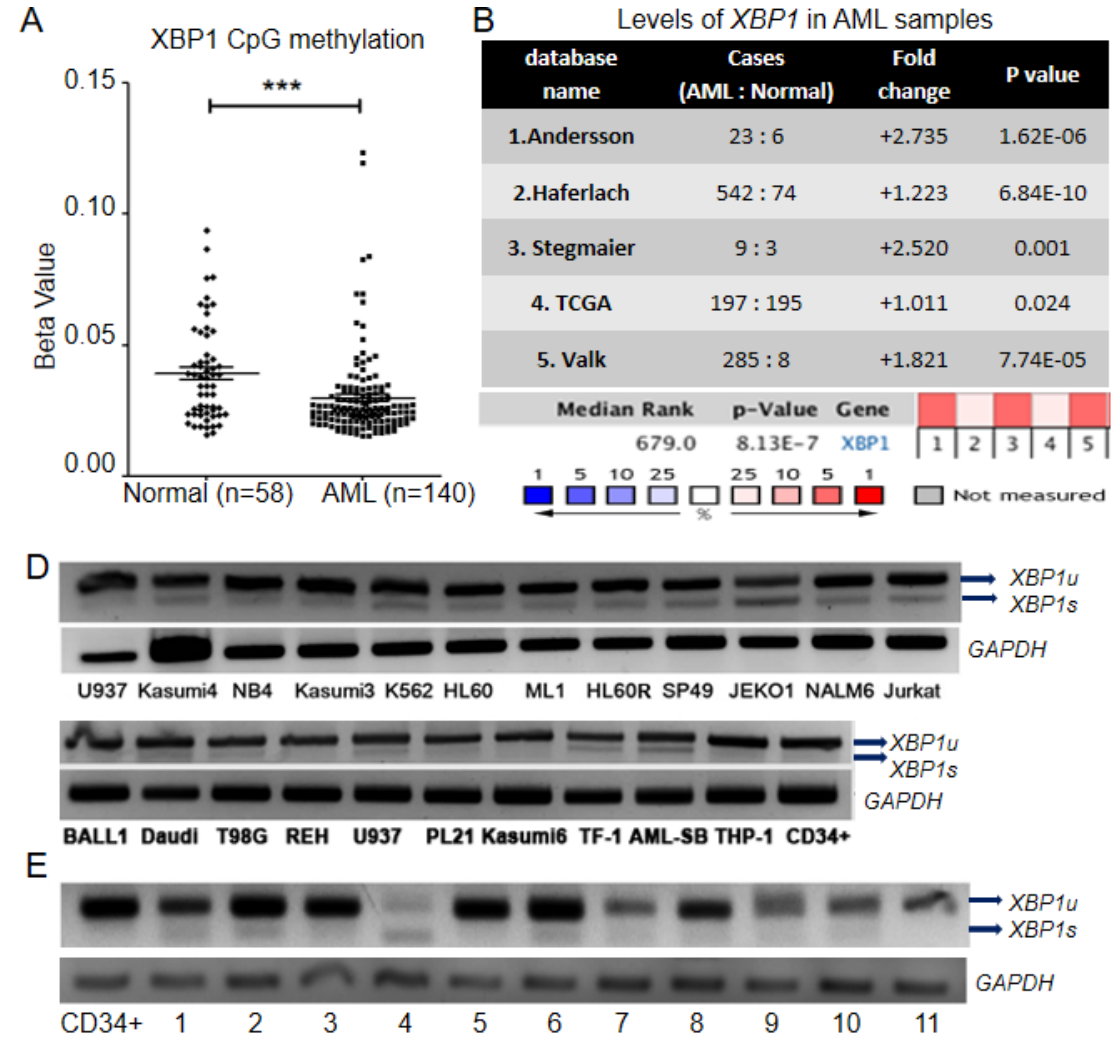
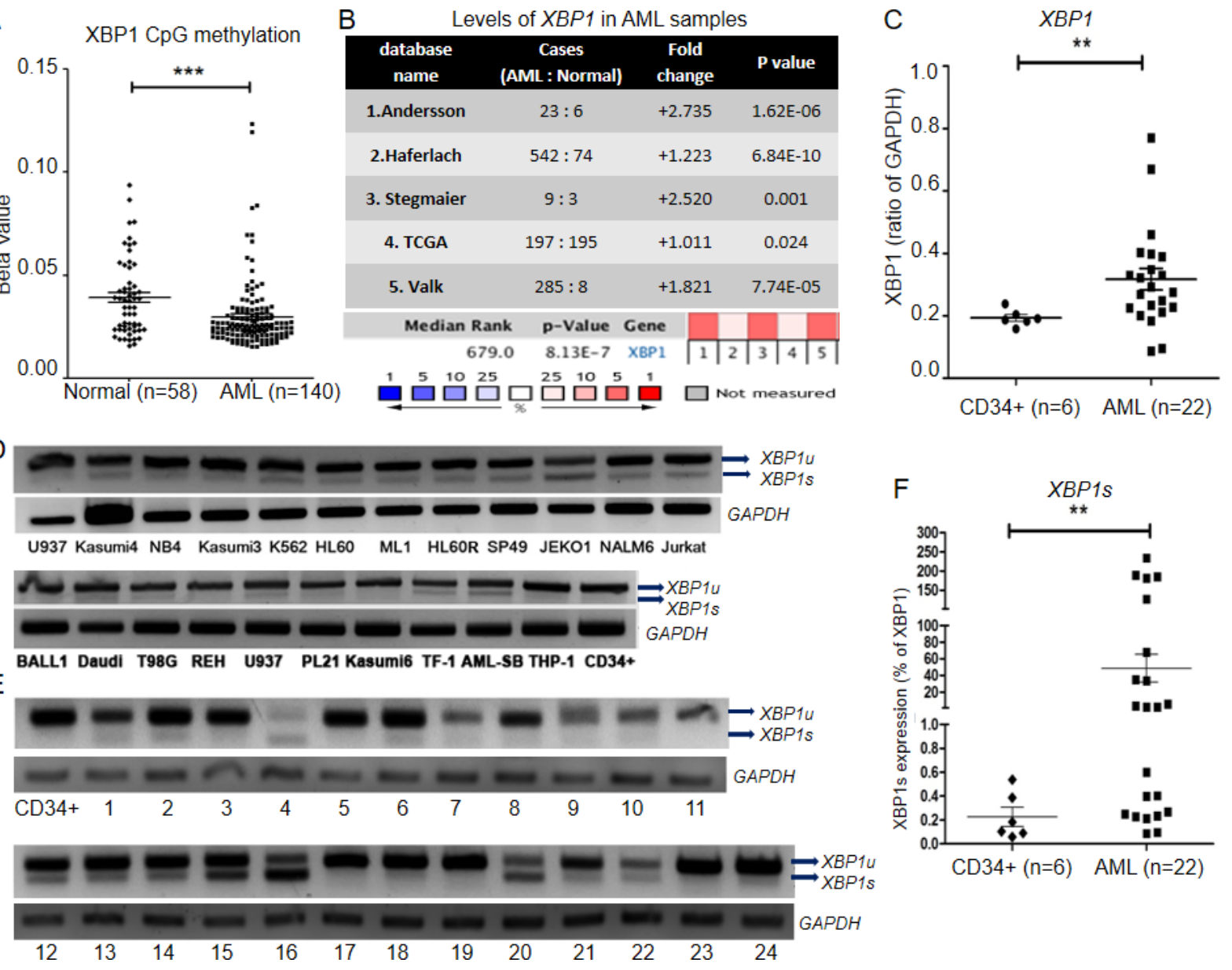

Figure 1: XBP1 and XBP1s are up-regulated in AML. A. The methylation status of the CpG islands of XBP1 in normal donors $(\mathrm{n}=58)$ and AML samples $(\mathrm{n}=140)$ was analyzed using TCGA level 3 database. The p-values were calculated by student $\mathrm{t}$ test. B. 5 publicly available microarray databases showed XBP1 was highly expressed in AML samples compared with normal BM samples. 1. Andersson Leukemia [84]; 2. Haferlach [85]; 3. Stegmaier [86]; 4. TCGA [87]; 5. Valk [88]. The rank for a gene is the median rank for that gene across each of the analyses. The p-value refers to the median-ranked analysis. C. QRT-PCR analysis of AML blast cells from patients ( $\mathrm{n}=22$ ) compared with normal human CD34+ cells $(n=6)$ showed significant up-regulation of XBP1, using GAPDH as an internal control $(\mathrm{p}<0.01)$. D, E. RT-PCR and gel electrophoresis identified XBP1s activation in human leukemia cell lines (D) and samples from normal (CD34+) and AML blast cells from patients (1-24) (E). F. QRT-PCR analysis of XBP1s expression in AML blast samples from patients (n=22) and normal human $\mathrm{CD} 34+$ cells $(\mathrm{n}=6)$. Figures are representative example of 3 replicates. Data represent mean $\pm \mathrm{SD} . X B P 1 s$, spliced XBP1. 
REH and K562 cell lines, and confirmed that the XBP1s protein levels were correlated with their mRNA levels. Specifically, K562 cells showed expression of both XBP1s mRNA and protein, whereas BALL1 and REH cells expressed neither mRNA nor protein of XBP1s (Figures 1D and S2D). Furthermore, we confirmed that the ER stress inducer thapsigargin successively induced XBP1s expression (Figure S2D).

\section{IRE1 $\alpha$ induced apoptosis and G1 cell cycle arrest in AML}

Inhibition of UPR blocks pro-survival pathways is implicated in apoptosis and cell-cycle arrest in several model systems [39]. In a dose-dependent manner, HNA treatment of AML cell lines and primary samples significantly increased the percent annexin $\mathrm{V}$ positive cells
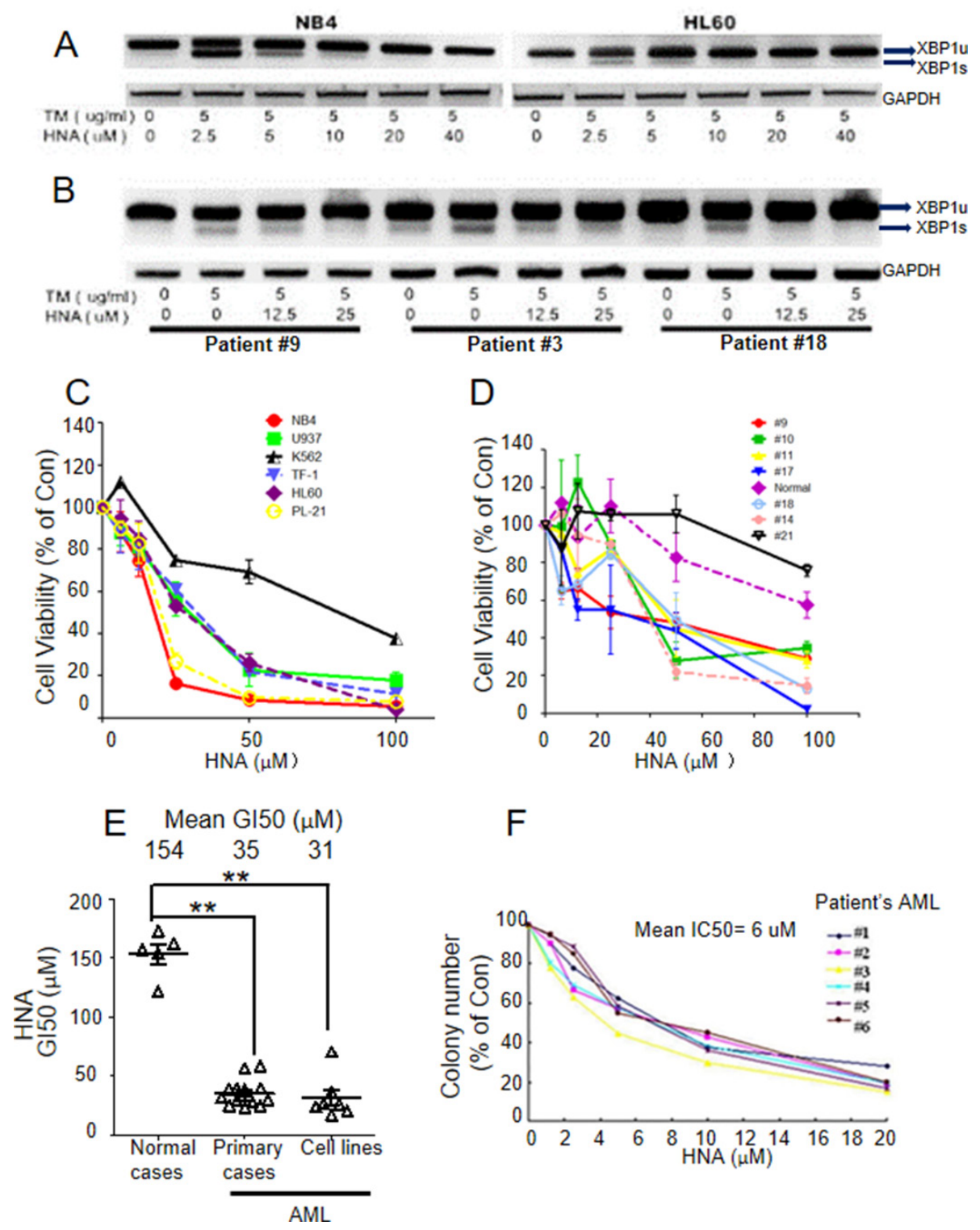

Figure 2: HNA inhibits XBP1s and causes cytotoxicity of AML cells. A, B. HNA inhibited $X B P 1 s$ expression induced by tunicamycin (TM) in human AML cells lines (A) and AML blast cells from patients (B). Cells $\left(10^{6}\right)$ were incubated with indicated concentrations of either TM or TM and 2-hydroxy-1-naphthaldehyde (HNA) in 6-well plates for $6 \mathrm{~h}$. RNA was isolated and RT-PCR was performed to examine $X B P 1 u$ and $X B P 1 s$ expression by gel electrophoresis. C, D. Cell viability analysis examined IRE1 inhibitor induced cytotoxicity of human AML cell lines (C) and AML blast samples from normal and AML patients (D). Cells $(10,000)$ were added into 96well plates followed by exposure to various concentrations of HNA. Cell viability (MTT assay) was examined $72 \mathrm{~h}$ later. E. Concentration for $50 \%$ of maximal inhibition of cell proliferation $\left(\mathrm{GI}_{50}\right.$ ) of HNA for 15 AML patient samples and 7 AML cell lines (NB4, U937, K-562, TF-1, HL-60, PL-21 and THP-1) calculated from data shown in Figures 2C and 2D. "Con", untreated control. The GI ${ }_{50 \text { s }}$ were calculated by Graphpad software. F. Soft agar clonogenic assays of 6 AML patient samples exposed to HNA. Figures are representative example of 3 replicates. $\mathrm{GI}_{50 \text { s }}$ were calculated. Data represent mean $\pm \mathrm{SD}, \mathrm{n}=3$. 
(Figures 3A, S4), increased the percent of cells in G1 of the cell cycle (Figure 3B), increased cleaved PARP and caspase-3 (Figure 3C), down-regulated Bcl-2 pro-survival family members (Bcl-2 and $\mathrm{Bcl}-\mathrm{xl})$, up-regulated the pro-apoptotic protein, Bim (Figures 3D, S5), increased G1 phase regulators (p21 cip1, $\left.27^{\text {kip } 1}\right)$, and decreased level of cyclin D1 (Figure 3D). Chaperone protein CHOP is up-regulated by ER stress and enhances ER stress induced apoptosis. However, other chaperone proteins such as Calnexin, HERPUD1, DNAJC3, DNAJB9 and EDEM are activated by UPR which is beneficial for cell survival during ER stress [40, 41]. Our results showed HNA treatment increased CHOP mRNA and protein (a chaperone molecule) (Figures 3D, 3E, S5). In contrast, several other chaperone genes Calnexin, HERPUD1, $D N A J C 3, D N A J B 9$ and EDEM were significantly downregulated by HNA (Figure $3 \mathrm{E}$ ). These results indicate that IRE1 $\alpha$ inhibition induced cell death by blockage of prosurvival UPR pathways and enhancement of pro-apoptotic pathways.

\section{Absence of Xbp1 in murine myeloid cells produced resistance to Ire1 $\alpha$ inhibitors}

To assess whether Xbp1 is a major driver of Ire $1 \alpha$ signaling pathway, we generated a model based on bone marrow progenitor cells from mice carrying a floxPflanked allele of Xbpl (Xbpl fox/flox $)$. After Cre activation,

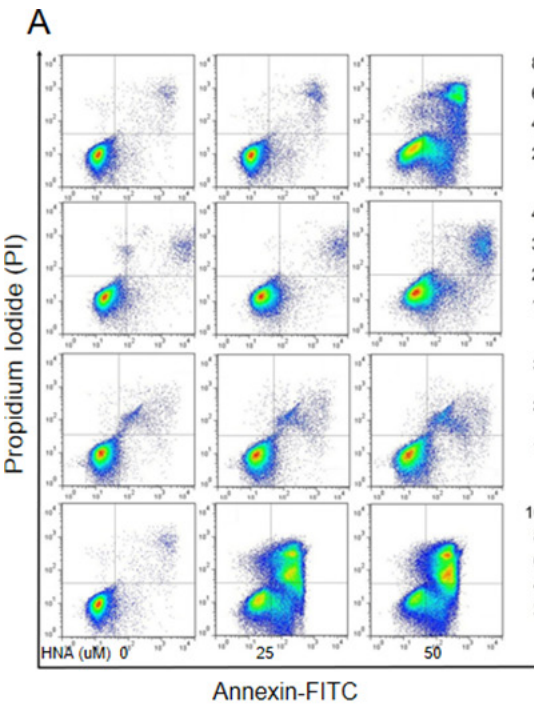

C

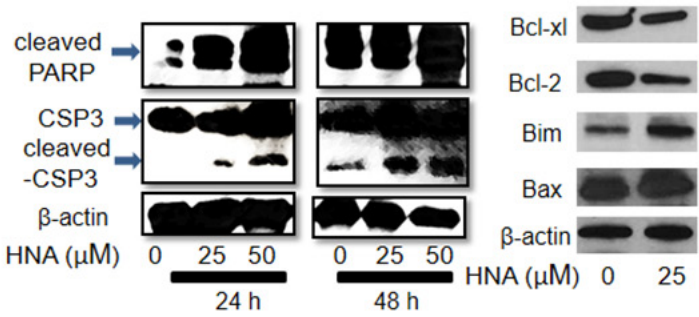

B

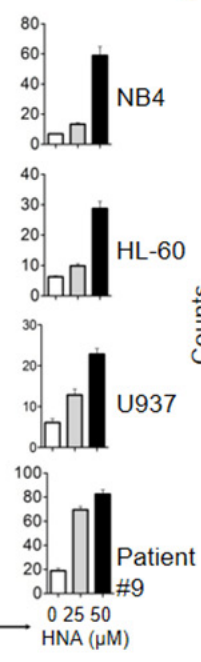

D

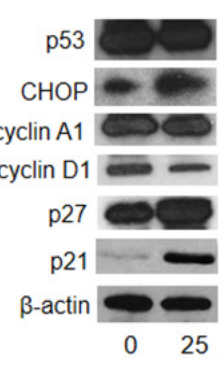

$\mathrm{E}$

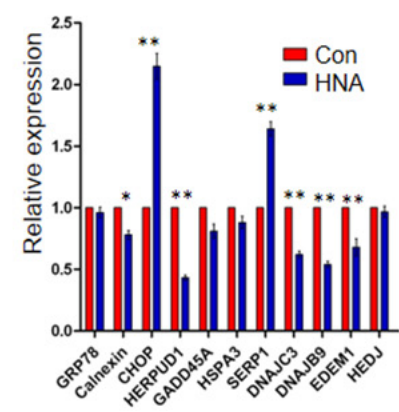

Figure 3: IRE1 $\alpha$ inhibition induced apoptosis and G1 cell cycle arrest in AML cells. A. AML cells (NB4, HL-60, U937 and AML patient sample \#9) were treated with HNA $(25 \mu \mathrm{M}, 50 \mu \mathrm{M})$ for $24 \mathrm{~h}$ and Annexin/PI assays were conducted to evaluate HNA induced apoptosis. Right side bar graphs show percent apoptotic cells (positive Annexin V+ PI) in each treatment group. B. AML cells (NB4, HL60, U937 and AML patient sample \#9) were treated with HNA $(25 \mu \mathrm{M}$ and $50 \mu \mathrm{M})$ for $24 \mathrm{~h}$ and stained with PI. Cell cycle was analyzed by Flowjo software. Right panel, bar graphs displayed cell cycle phase distribution in each treatment group. Cells cultured with diluent were used as control (Con). C. NB4 cells were treated with HNA $(25 \mu \mathrm{M}, 50 \mu \mathrm{M})$ for either 24 or $48 \mathrm{~h}$ and western blotting evaluated expression of cleaved PARP and cleaved caspase-3. $\beta$-actin was used as loading control. D, E. NB4 cells were treated with HNA ( $25 \mu \mathrm{M}, 48 \mathrm{~h})$ and expression of Bcl-2 family and cell cycle associated proteins were evaluated by western blotting ( $\beta$ - actin, loading control) (D); mRNA levels of chaperone genes were measured by QRT-PCR (E). Relative expression of each gene was normalized to GAPDH mRNA; and for each gene, control levels were considered to be 1.0. Figures (A, B, E) are representative example of 3 replicates. Data represent mean \pm $\mathrm{SD}, \mathrm{n}=3$. 
more than $92 \%$ of $X b p 1$ was confirmed to be deleted in the floxed cells as evidenced by QRT-PCR (Figure 4A). Ire $1 \alpha-\mathrm{Xbp} 1$ in vivo inhibition effect was confirmed as HNA decreased TM induced $X b p 1 s$ levels in bone marrow cells of mice (Figure S6). Myeloid cells (94\% CD34+) with deleted $X b p 1$ showed slower proliferation (Figure 4B) and increased resistance to both IRE1 $\alpha$ inhibitors (toyocamycin and HNA) (Figures 4C, 4D). Treatment with $\mathrm{TM}(1 \mathrm{mg} / \mathrm{ml})$ produced negligible cytotoxicity to the murine BM cells (Figure S8B). Combination of TM (1 $\mathrm{mg} / \mathrm{ml}$ ) with HNA, increased cell viability in $\mathrm{Xbp1}^{-/}$cells compared to vector control cells (Figures 4E), suggesting that Ire $1 \alpha$ induced UPR is at least partially reliant on $\mathrm{Xbp} 1$.

\section{Combination of HNA with either bortezomib or $\mathrm{AS}_{2} \mathrm{O}_{3}$ synergistically inhibited growth of $\mathrm{AML}$ cells}

Bortezomib is a potent $26 \mathrm{~S}$ proteasome inhibitor which induces terminal UPR and apoptosis in many cells [42-45]. $\mathrm{AS}_{2} \mathrm{O}_{3}$ is a leading therapy for treatment of acute promyelocytic leukemia (APL) [46] and has recently been shown to induce ER stress in cancer cells including leukemia cells $[47,48]$. Both drugs induced apoptosis associated with p-JNK activation in cancer cells [49, 50]. We hypothesized that the combination of an IRE1 $\alpha$ RNase inhibitor with either bortezomib or $\mathrm{AS}_{2} \mathrm{O}_{3}$, will enhance the inhibition of proliferation of AML cells. Indeed, various concentrations of either drug combined with HNA synergistically inhibited growth of both NB4 cells and an AML patient sample \#19 (Figures 5A-5D). Also, bortezomib induced expression of $\mathrm{p}-\mathrm{JNK}$, as well as reduced levels of p-MAPK and p-PI3K in NB4 cells. (Figure 5E).

\section{Inhibition of IRE1 $\alpha$ RNase activity increased the expression of selected miRs in AML}

Recent studies discovered that IRE1 $\alpha$ could cleave 4 anti-Casp2 pre-miRNAs (miR-17, -34a, -96, and -125b), resulting in activation of CASP2 in mouse embryonic fibroblasts (MEFs) [22, 23]. To assess whether the cleavage of miRs occurs in AML, we examined expression levels of pre-miRs upon treatment of NB4 AML cells with IRE1 $\alpha$ inhibitors. The pre-miRs $-17,-21,-34 \mathrm{a},-147$ and -150 were dramatically increased after exposure of the AML cells to IRE1 $\alpha$ inhibitor (HNA, 25, $50 \mu \mathrm{M}$ ) in a
A
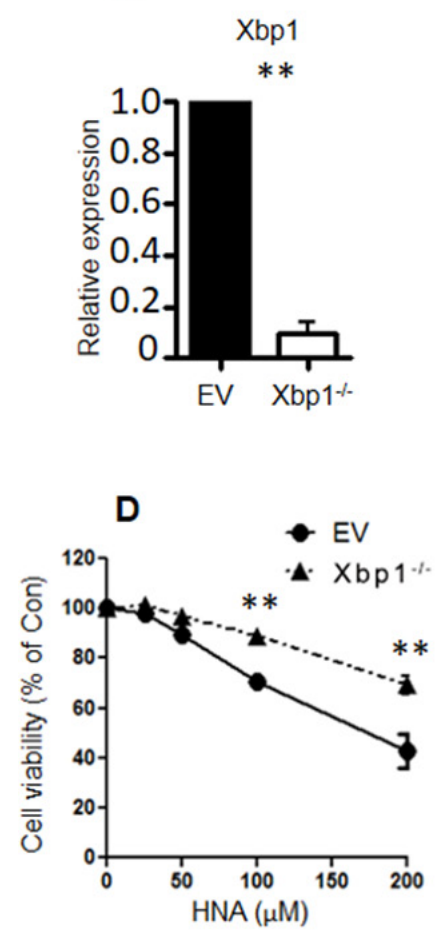

B
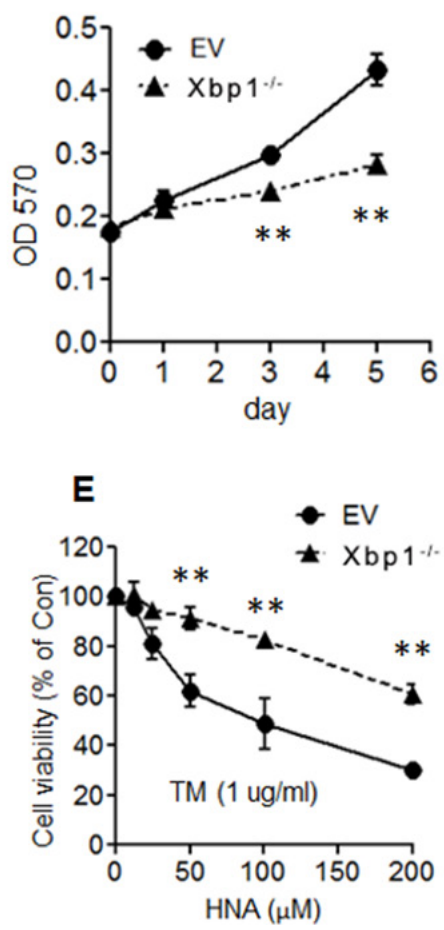

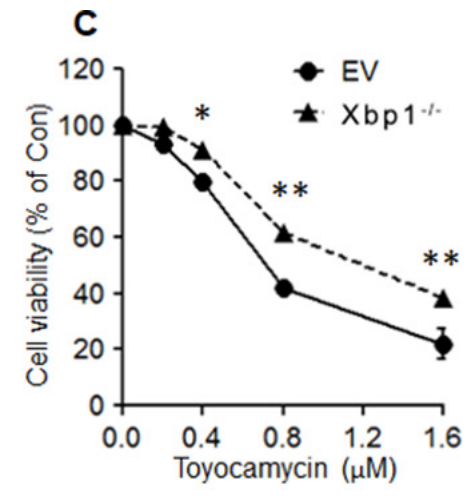

Figure 4: Knock-out Xbp1 induced myeloid cell resistance to IRE1 inhibitors. A. Xbp1 ${ }^{\text {flox/lox }}$ murine bone marrow cells were infected with a retroviral vector that expressed either the Cre recombinase or empty vector (EV); these cells were stably selected with G418 followed by addition of 4-OHT $(1 \mu \mathrm{M})$ for two days to obtain either Cre-mediated Xbp1 knock-out $\left(\mathrm{Xbp}^{-/}\right)$or empty vector $(\mathrm{EV}) \mathrm{Xbp} 1^{\mathrm{f} / \mathrm{fl}}$ myeloid cells. QRT-PCR was performed to measure knock-out effenciency of Xbp1. B. Xbp $1^{-/-}$and EV marrow cells $(1,000)$ were seeded into 96-well plates, and cell proliferation was measured on days 1, 3 and 5. (MTT assay) (n=3). C-E. Xbp $1^{-/}$and EV marrow cells were $(1,000)$ seeded into 96 -well plates and followed by treatment with increasing concentrations of IRE1 inhibitor [Toyocamycin alone (C); HNA alone (D); HNA or TM plus HNA (E)]. After 72h, cell viability was measured (MTT assay). Data represent mean $\pm \mathrm{SD}, \mathrm{n}=3$. 
dose-dependent manner (Figures 6A, 6B). Also, U937, HL60, KG-1 and K562 cells responded to the IRE1 inhibitor (HNA) by increasing the levels of miR-34a (Figure 6B). Furthermore, other IRE1 $\alpha$ inhibitors (STF-083010, $50 \mu \mathrm{M}$; Toyocamycin, $500 \mathrm{nM}$ ) dramatically increased miR-34a in AML cells (NB4, THP-1, K562, U-937, patients \#27 and $\# 28$, Figure $6 \mathrm{C})$. In contrast, exposure to TM (2.5 $\mu \mathrm{g} / \mathrm{ml}, 12 \mathrm{~h}$ ), a known IRE1 enhancer, slightly inhibited levels of miR-34a and miR-96 even in the presence of HNA $(25 \mu \mathrm{M} ; 12 \mathrm{~h})$ (Figure 6D). Actinomycin D, a DNA transcription inhibitor inhibited HNA induced miR-34a activation (Figure S7). In the presence of TM $(1-4 \mu \mathrm{g} / \mathrm{ml} ; 72 \mathrm{~h})$, murine myeloid cells with deletion of Xbp1 (following Cre activation) had no change in either the expression of miR $-34 \mathrm{a},-96,-147$ and -150 (Figure S8A) or in cell growth (Figure S8B). Murine BM cells treated with $\mathrm{HNA}(25,50 \mu \mathrm{M} ; 12 \mathrm{~h})$ also displayed a dosedependent increase of pre-miRs which was independent of Xbp1 (Figure S8C), suggesting that this regulation might be directly through IRE1-driven RIDD.

\section{miR-34a triggered sensitivity of IRE1 inhibitor in vitro}

Small RNA antagonist against miR-34a was transiently transfected into 3 AML cell lines (K562, NB4, U937), and cell viability was examined after treatment with HNA (12.5-100 $\mu \mathrm{M})$. Knockdown efficiency of
miR-34a by the antagonist was validated both at the preand mature miR level by QRT-PCR (Figures 7A-7C, left panels). Inhibition of miR-34a conferred modest survival advantage compared to HNA alone in these AML cells (Figures 7A-7C, right panels). In addition, HNA inhibited transcriptional levels of several targeted genes of miR-34a (c-Myc, cyclin D1, CDK4) in NB4 cells (Figure 7D); Also in the AML cells, the miR-34a antagonist restored protein expression levels of c-Myc and cyclin D1 proteins, these had been inhibited in their expression in the presence of HNA alone. (Figure 7E).

\section{DISCUSSION}

The UPR is a defense mechanism activated by cells during stressful conditions in response to an accumulation of misfolded proteins in the ER [51]. Cancer cells are usually exposed to many stressful environments (e.g. hypoxia, nutrient starvation, oxidative stress and other metabolic dysregulation) resulting in continued ER stress. Furthermore, genomic mutations can also lead to accumulation of misfolded proteins. The UPR is often activated to help cancer cells escape from ER stressinduced cell death [52]. Reactive oxygen species (ROS) in AML cells can also stimulate ER stress and the UPR $[11,53,54]$. Studies have particularly focused on the functional roles of UPR proteins in multiple myeloma cells because chronic ER stress occurs in these cells
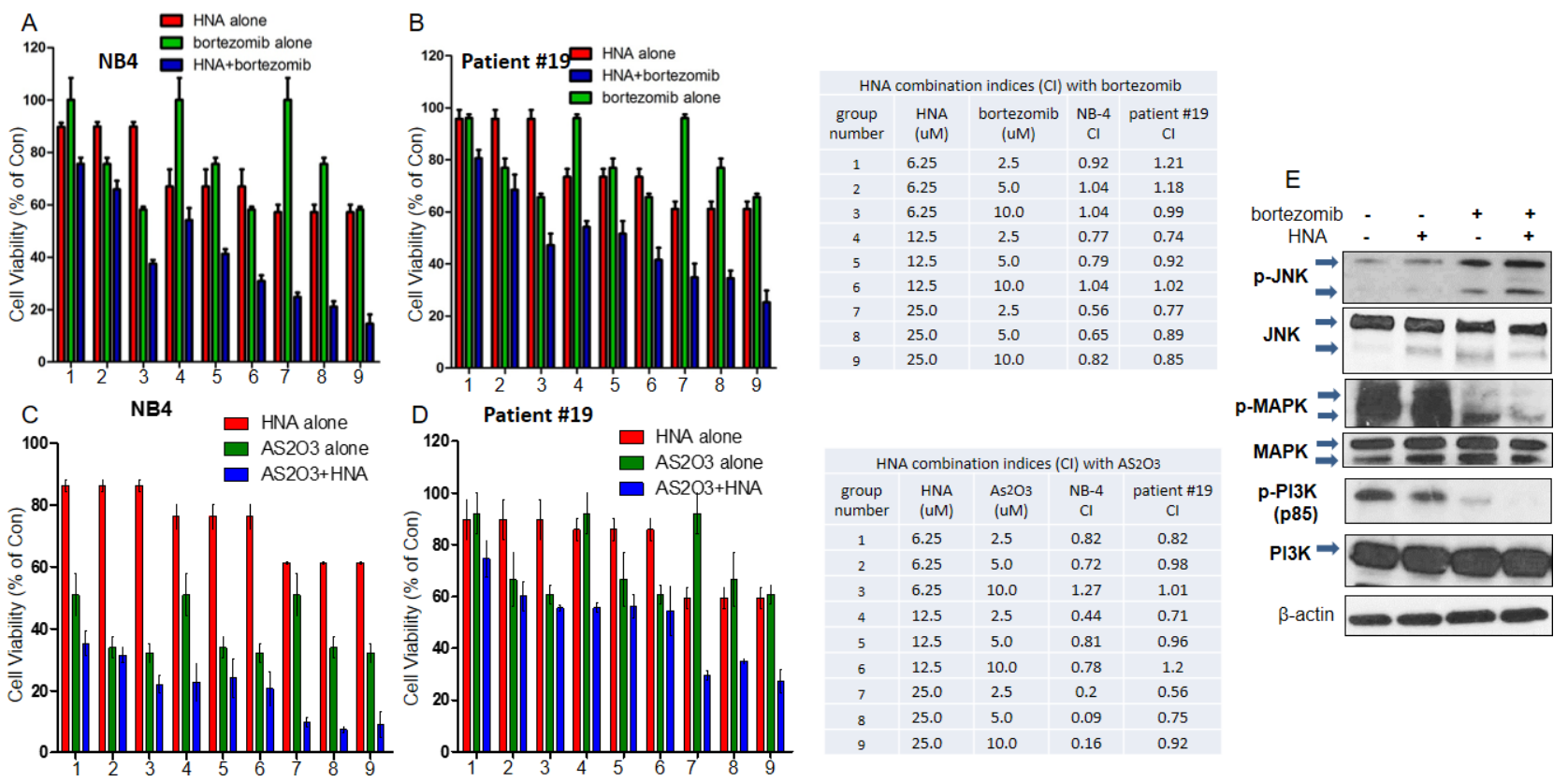

Figure 5: Combination of HNA with either bortezomib or $\mathbf{A S}_{2} \mathbf{O}_{3} \mathbf{N B} 4$. A, C. or \#19 primary AML blast cells B, D. were seeded $(10,000)$ in 96 -well plates and treated with $\operatorname{HNA}(0,6.25,12.5$ and $25 \mu \mathrm{M})$ and/ or bortezomib $(0,2.5,5,10 \mu \mathrm{M})(\mathrm{A}, \mathrm{B})$ or HNA and/or $\mathrm{AS}_{2} \mathrm{O}_{3}(0,2.5,5,10 \mu \mathrm{M})(\mathrm{C}, \mathrm{D})$ for $72 \mathrm{~h}$; and cell viability was measured (MTT assay). Data are presented as percentage of diluent treatment control (Con). Data represent mean $\pm \mathrm{SD}, \mathrm{n}=3$. CI ( $<1$, synergistic; $=1$, additive; $>1$, antagonistic). E. NB4 cells were treated with HNA ( 25 $\mu \mathrm{M})$ and/or botezomib $(5 \mu \mathrm{M})$ for $48 \mathrm{~h}$, and expression of total and phosphorylated (p-) JNK, MAPK and PI3K were evaluated by western blotting ( $\beta$ - actin, loading control). 
$[37,55,56]$. Activation of the unfolded protein response including XBP1 splicing has been noted in AML samples $[26,27]$. In our study, we confirmed that one of the major branches of the UPR (IRE1-XBP1s) is frequently activated in AML cell lines and AML patient samples, suggesting that targeting the UPR may be a promising adjunctive approach for treatment of AML.

XBP1 and its spliced form XBP1s have been reported to be upregulated in several types of cancers, and blockage of the IRE1/XBP1 pathway is considered as a promising therapeutic option [55, 57-61]. XBP1 is one of the most well studied genes modulated by IRE1 $\alpha$, which has important roles in the regulation of cell survival and UPR as a downstream target of IRE1 $\alpha$ [55, 62-65]. However, XBP1 is not the only factor in response to IRE $1 \alpha$ inhibition. In fact, as an RNase, IRE $1 \alpha$ recognizes and cleaves a consensus element, CUGCAG, in target RNAs upon cellular stresses [66]. Therefore, IRE1 $\alpha$ has the capacity to target directly a number of RNAs (both coding and noncoding) and regulate their expression levels through Regulated IRE1-Dependent Decay (RIDD). For example, in a recent study using MEF cells, IRE1 $\alpha$ was found to cleave four anti-CASP2 miRs (miR-17, -34, -96 and -125) $[22,23]$. Based on our bioinformatic analysis of miRs and RNA microarray results, we found that many pre-miRs with IRE1 $\alpha$ cutting consensus motif were upregulated upon HNA treatment. We focused on 5 of these candidate miRs and QRT-PCR results demonstrated that they were induced in the presence of IRE1 $\alpha$ inhibitors (Figure 6). Together, these results suggest that the antineoplastic effects of IRE1 $\alpha$ inhibitors are the results of the enhanced nuclease activity that generates not only XBP1s, but also a number of other RNAs, including miRNAs.

We particularly focused on miR34a. Recent studies indicate that miR-34a is a tumor suppressor [67]. Downregulation of miR-34a causes resistance to chemotherapy [67-69]. Targets of miR-34a include caspase-2, c-Myc, Bcl-2, cyclin D1, MET and SIRT1. miR-34a dependent inhibition of SIRT1 can increase acetylation and activation of p53 resulting in up-regulation of p21 and PUMA [70]. By post-transcriptional blockade of these genes, miR-34a suppresses migration and induces apoptosis, G1 cycle arrest and senescence in cancer cells [71, 72]. Our study showed that IRE1 $\alpha$ inhibitors significantly increased pre- and mature miR-34a mRNA levels, associated with inhibition of $C D K 4$, $c-M y c, B c l-2$ and Cyclin DI and induction of $p 21^{c i p l}$ and
A
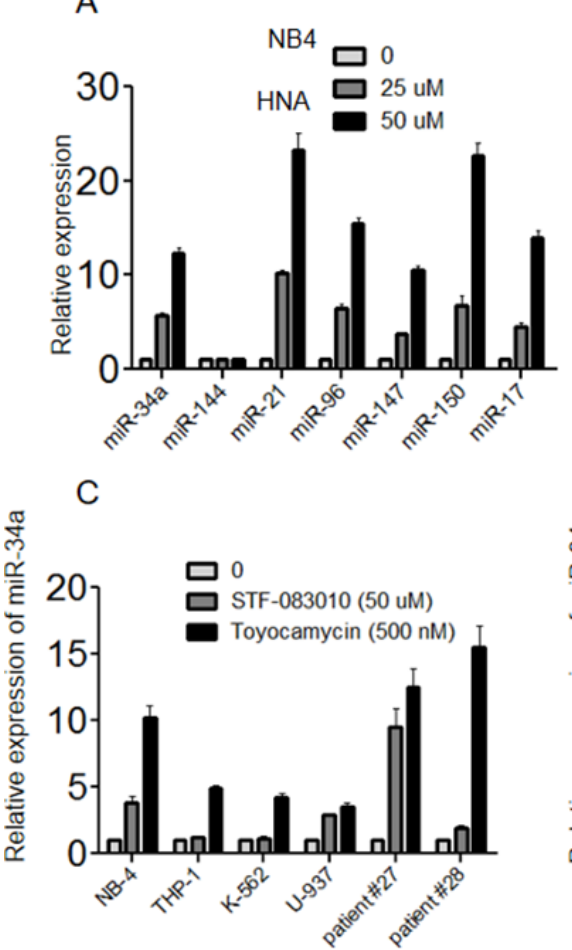

B
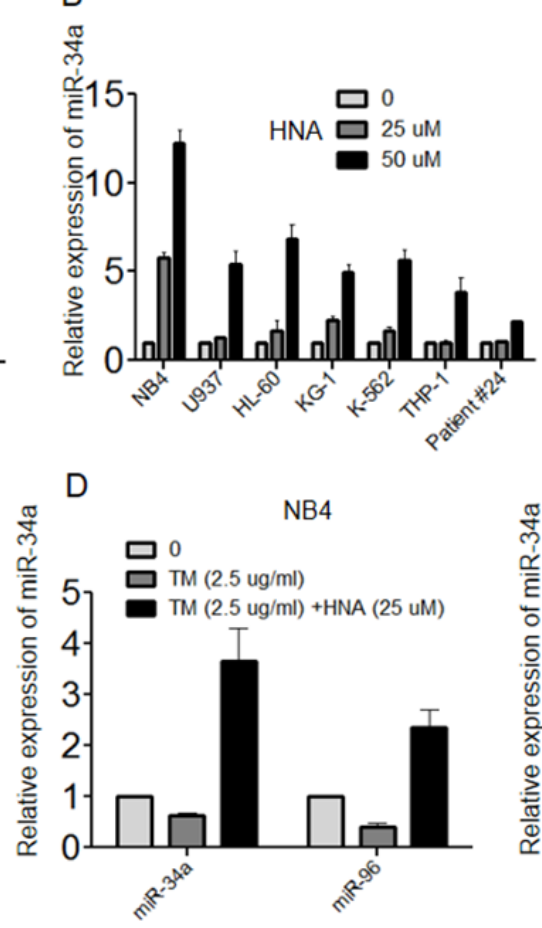

Figure 6: Inhibition of IRE1 $\alpha$ increased expression of miRs in AML cells. A. NB4 cells were treated with HNA $(0,25,50 \mu M)$ for 24h and expression of pre-miR- 34, -144, -21, -96,-147 and -150 was measured by QRT-PCR. Cells without HNA were used as control. B. QRT-PCR analysis of pre-miR-34a expression level in NB4, U937, HL-60, KG-1, K-562 and THP-1 AML cell lines and primary AML blast sample \#24 upon HNA $(25 \mu \mathrm{M})$ treatment for $24 \mathrm{~h}$. C. QRT-PCR analysis of pre-miR-34a expression level in NB4, THP-1, K-562 and U937 AML cell lines and primary AML blast cell samples \#27 and \#28 after exposure to either STF-083010 (50 $\mu$ M) or Toyocamycin (500 $\mathrm{nM})$ for $24 \mathrm{~h}$. D, E. NB4 or HL-60 cells were treated with either TM $(2.5 \mu \mathrm{g} / \mathrm{ml})$ alone or TM and HNA $(25 \mu \mathrm{M})$ for $12 \mathrm{~h}$; expression levels of pre- miR-34a and miR-96 were measured by QRT-PCR. Relative expression of each gene was normalized to GAPDH. Data represent mean $\pm \mathrm{SD}, \mathrm{n}=3$. 
$p 27^{k i p 1}$ in AML cells. Silencing of miR-34a by small RNA antagonist significantly induced resistance of AML cells to IRE1 $\alpha$ inhibitors and restored levels of miR-34a targeted oncogenes such as c-Myc and Cyclin D1. These results indicate that miR-34a plays an important role in IRE1 $\alpha$ dependent UPR in AML. Through cleavage of miR-34a, IRE1 $\alpha$ decreases miR-34a induced apoptosis and helps AML cells to escape death.

Bortezomib is a proteasome inhibitor which has been approved by FDA as the first example of UPRmodulating regimen for the treatment of Multiple Myeloma [73]. Recently, bortezomib was also approved for treatment of mantle cell lymphoma [74]. In the context of AML, several clinical studies have shown that bortezomib has potent anti-neoplastic activity, and the mechanisms include induction of apoptosis and transcriptional inactivation of several important AMLdrivers such as DNA methyltransferases (DNMTs)
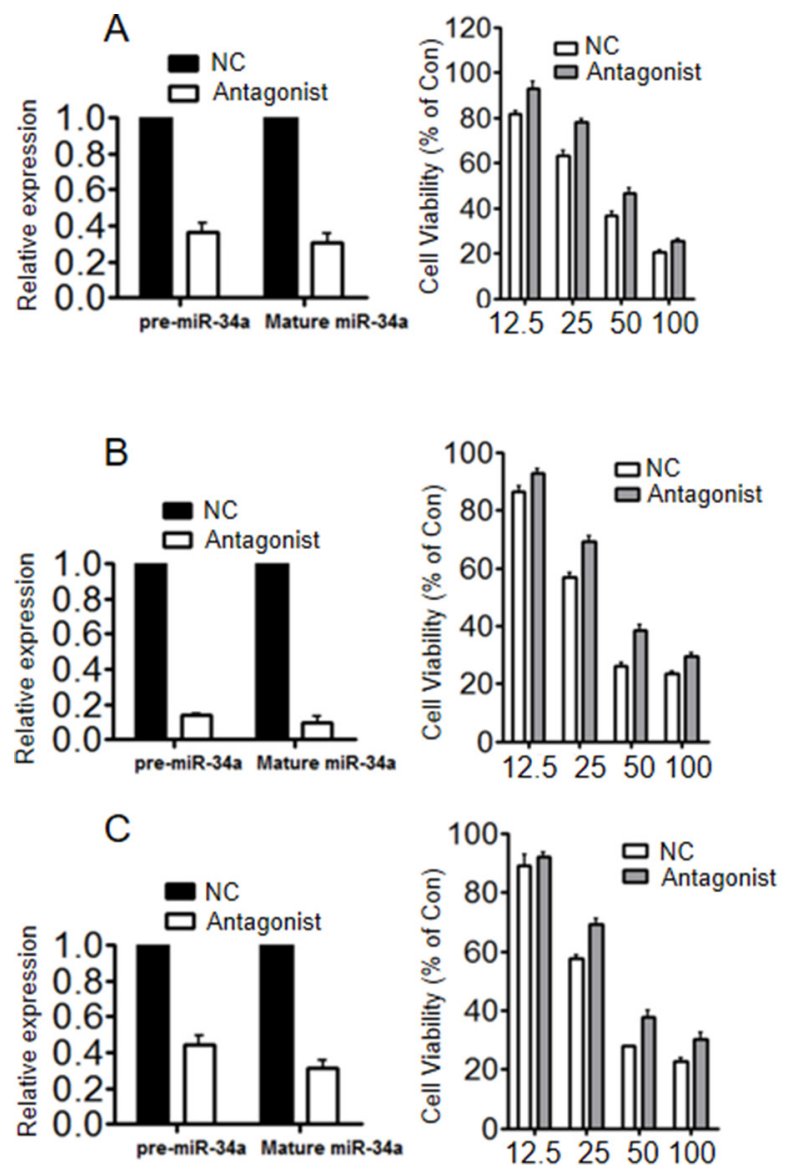

and receptor tyrosine kinases (RTKs) [29, 38, 75, 76]. Moreover, bortezomib has shown greater therapeutic value when applied in combination with traditional cytotoxic chemotherapies to treat AML [31, 77, 78]. Therefore, although not yet approved by FDA, bortezomib has demonstrated its promising therapeutic merit and is considered as one of the candidate drugs for the treatment of AML. On the other hand, several studies have shown that IRE $1 \alpha$ inhibitors in combination with bortezomib strongly impaired the growth of multiple myeloma cells both in vitro and in vivo $[37,55]$. Mechanistically, IRE1 $\alpha$ inhibition can overcome the tumor cytoprotective effects conferred by bortezomib-induced UPR via activation of XBP1s [55]. In the present study, we also showed that combined addition of HNA with bortezomib synergistically increased apoptosis of AML cells associated with the up-regulation of CHOP and p-JNK. Therefore, we believe that our results will provide useful

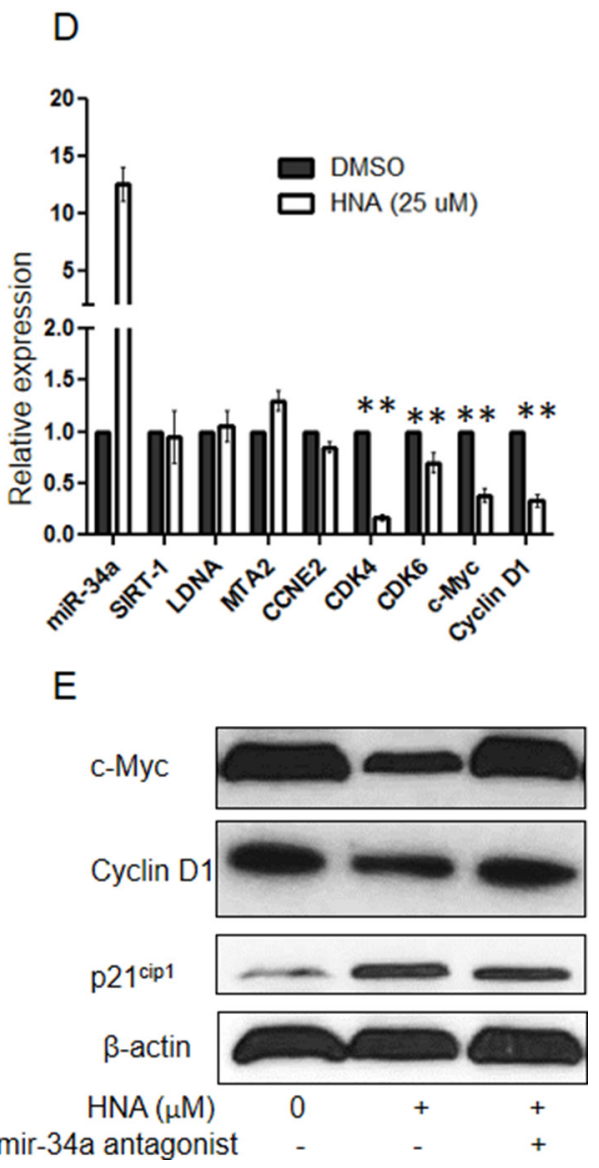

Figure 7: Blockade of miR-34a decreased sensitivity of IRE1 inhibitor in vitro. A-C. miR-34a small RNA antagonist or control small RNA were transiently transfected and knock-down efficiencies of either pre-miR-34a or mature miR-34a were evaluated by QRTPCR in K562 (A, left side), NB4 (B, left side) and U937 (C, left side). At 24 h after transfection, cells (10,000) were seeded into 96-well plates followed by treatment with $\operatorname{HNA}(0,12.5,25,50 \mu \mathrm{M})$ for $72 \mathrm{~h}$, and cell viability was measured (MTT assay) (A-C, right side). D. NB4 cells were treated with HNA $(25 \mu \mathrm{M}, 24 \mathrm{~h})$ or diluent control. mRNA expression levels of pre-miR-34a, SRRT-1, LDNA, MTA2, CCNE2, CDK4, CDK6, c-Myc and cyclin D1 were measured by QRT-PCR. Relative expression of each gene was normalized to GAPDH. E. At $48 \mathrm{~h}$ after transfection of miR-34a antagonist or control siRNA, NB4 cells were treated with HNA ( $25 \mu \mathrm{M}, 48 \mathrm{~h})$ or diluent control, and protein expressions of c-Myc, cyclin D1 and $\mathrm{p} 21^{\text {cip } 1}$ were evaluated by western blotting ( $\beta$ - actin as loading control). Data represent mean $\pm \mathrm{SD}, \mathrm{n}=3$. 
information to the investigators who are interested in developing bortezomib for the treatment of AML.

Treatment of acute promyelocytic leukemia (APL) with $\mathrm{AS}_{2} \mathrm{O}_{3}$ has unique favorable cure rates [79], and the major mechanism of action is through the degradation of PML-RAR $\alpha$, the driver of APL [80]. Notably, $\mathrm{AS}_{2} \mathrm{O}_{3}$ has been reported to enhance UPR by increasing the expression of GRP78, CHOP, phosphorylated eIF2 $\alpha$ and ATF4 [81, 82]. In our study, the combination of HNA and $\mathrm{AS}_{2} \mathrm{O}_{3}$ synergistically increased cell apoptosis of the APL cells NB4, which might be due to corroborative inhibition of different branches of the UPR pathway. In the previous clinical trials, QT interval prolongation and APL differentiation syndrome are the most serious side-effects of $\mathrm{AS}_{2} \mathrm{O}_{3}$ treatment [83]. The combined use of HNA and $\mathrm{AS}_{2} \mathrm{O}_{3}$ may improve the toxicity profile.

In conclusion, we found that $X B P 1$ and its spliced form $(X B P 1 s)$ are often increased in AML. Inhibition of IRE1 $\alpha$ RNase activity by small molecules inhibited AML cell growth. This inhibition of proliferation probably occurred by inducing ER stress by blocking the compensatory pathways including the prevention of cleavage of tumor suppressor miRs (e.g. miR-34a) which may augment the anti-proliferative effect of IRE1 $\alpha$ inhibitors. Therefore, compounds which inhibit activation of IRE1 $\alpha$ represent a novel pathway for cell kill and may be a useful compliment to chemotherapy.

\section{MATERIALS AND METHODS}

Information of reagents and vendors, and all methods are described in the Supplemental Methods.

\section{Abbreviations}

AML, acute myeloid leukemia; $\mathrm{AS}_{2} \mathrm{O}_{3}$, arsenic trioxide; UPR, unfolded protein response; HNA, 2-hydroxy-1-naphthaldehyde; LSCs, leukemic stem cells; HSCs, Multipotent hematopoietic stem cells; ER, endoplasmic reticulum; IRE1 $\alpha$, Inositol-requiring enzyme 1 alpha; ERAD, Endoplasmic-reticulumassociated protein degradation; RIDD, Regulated IRE1Dependent Decay; MTT, 3-(4,5-dimethylthiazol-2-yl)2,5-diphenyltetrazolium bromide; TCGA, The Cancer Genome Atlas; n, denotes the number of independent experiments; HL60R, HL60 derived all-trans retinoic acid (ATRA) resistant cell line.

\section{ACKNOWLEDGMENTS}

We thank Sally Chi for collecting Cord blood samples and Dr. L. Glimcher for Xbp $1^{\text {flox/flox }}$ murine BM cells. This research was supported by the National Research Foundation Singapore and the Singapore Ministry of Education under the Research Centres of Excellence initiative as well as the Singapore Ministry of Health's National Medical Research Council under its Singapore Translational Research (STaR) Investigator Award, as well as NIH grant R01CA026038-35 (H.P.K). D-C.L was supported by American Society of Hematology Fellow Scholar Award, Donna and Jesse Garber Awards for Cancer Research, and Myelodysplastic Syndromes Foundation Young Investigator Grant. We also thank Steven and Blanche Koegler for their support of this study.

\section{Authorship}

Contribution: H.S. designed research, performed experiments, analyzed data, and wrote the manuscript; X.G., B.K.M., Q.C., C.A., Y.J and K.A performed experiments; S.G., W.C., and T.Y provided new ideas; S.A., T.I., R.P., C.M and M.M contributed the vital new reagent and clinical samples; D-C.L and H.P.K helped to guide the project as well as assisted in writing the manuscript;

\section{CONFLICTS OF INTEREST}

The authors declare no conflicts of interest

\section{REFERENCES}

1. Lowenberg B, Downing JR, Burnett A. Acute myeloid leukemia. N Engl J Med. 1999; 341:1051-1062.

2. Giles FJ, Keating A, Goldstone AH, Avivi I, Willman CL, Kantarjian HM. Acute myeloid leukemia. Hematology Am Soc Hematol Educ Program. 2002:73-110.

3. Konopleva MY, Jordan CT. Leukemia stem cells and microenvironment: biology and therapeutic targeting. J Clin Oncol. 2011; 29:591-599.

4. Bonnet D, Dick JE. Human acute myeloid leukemia is organized as a hierarchy that originates from a primitive hematopoietic cell. Nat Med. 1997; 3:730-737.

5. Chan WI, Huntly BJ. Leukemia stem cells in acute myeloid leukemia. Semin Oncol. 2008; 35:326-335.

6. Horton SJ, Huntly BJ. Recent advances in acute myeloid leukemia stem cell biology. Haematologica. 2012; 97:966-974.

7. Welch JS, Ley TJ, Link DC, Miller CA, Larson DE, Koboldt DC, Wartman LD, Lamprecht TL, Liu F, Xia J, Kandoth C, Fulton RS, McLellan MD, Dooling DJ, Wallis $\mathrm{JW}$, Chen K, et al. The origin and evolution of mutations in acute myeloid leukemia. Cell. 2012; 150:264-278.

8. O'Donnell MR, Appelbaum FR, Baer MR, Byrd JC, Coutre SE, Damon LE, Erba HP, Estey E, Foran J, Lancet J, Maness LJ, Maslak PG, Millenson M, Moore JO, Przepiorka D, Shami P, et al. Acute myeloid leukemia clinical practice guidelines in oncology. J Natl Compr Canc Netw. 2006; 4:16-36.

9. Cornelissen JJ, van Putten WL, Verdonck LF, Theobald M, Jacky E, Daenen SM, van Marwijk Kooy M, Wijermans P, Schouten H, Huijgens PC, van der Lelie H, Fey M, 
Ferrant A, Maertens J, Gratwohl A, Lowenberg B. Results of a HOVON/SAKK donor versus no-donor analysis of myeloablative HLA-identical sibling stem cell transplantation in first remission acute myeloid leukemia in young and middle-aged adults: benefits for whom? Blood. 2007; 109:3658-3666.

10. Hole PS, Darley RL, Tonks A. Do reactive oxygen species play a role in myeloid leukemias? Blood. 2011; 117:5816-5826.

11. Rouault-Pierre K, Lopez-Onieva L, Foster K, AnjosAfonso F, Lamrissi-Garcia I, Serrano-Sanchez M, Mitter R, Ivanovic Z, de Verneuil H, Gribben J, Taussig D, Rezvani HR, Mazurier F, Bonnet D. HIF-2alpha Protects Human Hematopoietic Stem/Progenitors and Acute Myeloid Leukemic Cells from Apoptosis Induced by Endoplasmic Reticulum Stress. Cell Stem Cell. 2013; 13:549-563.

12. Giuntoli S, Rovida E, Gozzini A, Barbetti V, Cipolleschi MG, Olivotto M, Dello Sbarba P. Severe hypoxia defines heterogeneity and selects highly immature progenitors within clonal erythroleukemia cells. Stem Cells. 2007; 25:1119-1125.

13. Ni M, Lee AS. ER chaperones in mammalian development and human diseases. FEBS Lett. 2007; 581:3641-3651.

14. Schroder M, Kaufman RJ. ER stress and the unfolded protein response. Mutat Res. 2005; 569:29-63.

15. Wang G, Yang ZQ, Zhang K. Endoplasmic reticulum stress response in cancer: molecular mechanism and therapeutic potential. Am J Transl Res. 2010; 2:65-74.

16. Ma Y, Hendershot LM. The role of the unfolded protein response in tumour development: friend or foe? Nat Rev Cancer. 2004; 4:966-977.

17. Valastyan JS, Lindquist S. Mechanisms of protein-folding diseases at a glance. Dis Model Mech. 7:9-14.

18. Moenner M, Pluquet O, Bouchecareilh M, Chevet E. Integrated endoplasmic reticulum stress responses in cancer. Cancer Res. 2007; 67:10631-10634.

19. Chen Y, Brandizzi F. IRE1: ER stress sensor and cell fate executor. Trends Cell Biol. 2013; 23:547-555.

20. Han D, Lerner AG, Vande Walle L, Upton JP, Xu W, Hagen A, Backes BJ, Oakes SA, Papa FR. IRE1alpha kinase activation modes control alternate endoribonuclease outputs to determine divergent cell fates. Cell. 2009; 138:562-575.

21. Krumschnabel G, Sohm B, Bock F, Manzl C, Villunger A. The enigma of caspase-2: the laymen's view. Cell Death Differ. 2009; 16:195-207.

22. Upton JP, Wang L, Han D, Wang ES, Huskey NE, Lim L, Truitt M, McManus MT, Ruggero D, Goga A, Papa FR, Oakes SA. IRE1alpha cleaves select microRNAs during ER stress to derepress translation of proapoptotic Caspase-2. Science. 2012; 338:818-822.

23. Hassler J, Cao SS, Kaufman RJ. IRE1, a double-edged sword in pre-miRNA slicing and cell death. Dev Cell. 2012; 23:921-923.
24. Lerner AG, Upton JP, Praveen PV, Ghosh R, Nakagawa Y, Igbaria A, Shen S, Nguyen V, Backes BJ, Heiman M, Heintz N, Greengard P, Hui S, Tang Q, Trusina A, Oakes $\mathrm{SA}$, et al. IRE1alpha induces thioredoxin-interacting protein to activate the NLRP3 inflammasome and promote programmed cell death under irremediable ER stress. Cell Metab. 2012; 16:250-264.

25. Anthony TG, Wek RC. TXNIP switches tracks toward a terminal UPR. Cell Metab. 2012; 16:135-137.

26. Tanimura A, Yujiri T, Tanaka Y, Tanaka M, Mitani N, Nakamura Y, Ariyoshi K, Tanizawa Y. Activation of the unfolded protein response in primary acute myeloid leukemia cells. Int J Hematol. 2011; 94:300-302.

27. Schardt JA, Eyholzer M, Timchenko NA, Mueller BU, Pabst T. Unfolded protein response suppresses CEBPA by induction of calreticulin in acute myeloid leukaemia. Journal of cellular and molecular medicine. 2010; 14:1509-1519.

28. Fang J, Rhyasen G, Bolanos L, Rasch C, Varney M, Wunderlich M, Goyama S, Jansen G, Cloos J, Rigolino C, Cortelezzi A, Mulloy JC, Oliva EN, Cuzzola M, Starczynowski DT. Cytotoxic effects of bortezomib in myelodysplastic syndrome/acute myeloid leukemia depend on autophagy-mediated lysosomal degradation of TRAF6 and repression of PSMA1. Blood. 2012; 120:858-867.

29. Colado E, Alvarez-Fernandez S, Maiso P, Martin-Sanchez J, Vidriales MB, Garayoa M, Ocio EM, Montero JC, Pandiella A, San Miguel JF. The effect of the proteasome inhibitor bortezomib on acute myeloid leukemia cells, drug resistance associated with the CD34+ immature phenotype. Haematologica. 2008; 93:57-66.

30. Riccioni R, Senese M, Diverio D, Riti V, Buffolino S, Mariani G, Boe A, Cedrone M, Lo-Coco F, Foa R, Peschle C, Testa U. M4 and M5 acute myeloid leukaemias display a high sensitivity to Bortezomib-mediated apoptosis. Br J Haematol. 2007; 139:194-205.

31. Attar EC, Johnson JL, Amrein PC, Lozanski G, Wadleigh M, DeAngelo DJ, Kolitz JE, Powell BL, Voorhees P, Wang ES, Blum W, Stone RM, Marcucci G, Bloomfield $\mathrm{CD}$, Moser B, Larson RA. Bortezomib added to daunorubicin and cytarabine during induction therapy and to intermediate-dose cytarabine for consolidation in patients with previously untreated acute myeloid leukemia age 60 to 75 years: CALGB (Alliance) study 10502. Journal of clinical oncology. 2013; 31:923-929.

32. Sarlo C, Buccisano F, Maurillo L, Cefalo M, Di Caprio L, Cicconi L, Ditto C, Ottaviani L, Di Veroli A, Del Principe MI, Grasso MA, Nasso D, De Santis G, Amadori S, Venditti A. Phase II Study of Bortezomib as a Single Agent in Patients with Previously Untreated or Relapsed/Refractory Acute Myeloid Leukemia Ineligible for Intensive Therapy. Leuk Res Treatment. 2013; 2013:705714.

33. Glimcher LH. XBP1: the last two decades. Ann Rheum Dis. 2010; 69:i67-71. 
34. Mimura N, Fulciniti M, Gorgun G, Tai YT, Cirstea D, Santo L, Hu Y, Fabre C, Minami J, Ohguchi H, Kiziltepe T, Ikeda H, Kawano Y, French M, Blumenthal M, Tam V, et al. Blockade of XBP1 splicing by inhibition of IRE1alpha is a promising therapeutic option in multiple myeloma. Blood. 119:5772-5781.

35. Kriss CL, Pinilla-Ibarz JA, Mailloux AW, Powers JJ, Tang $\mathrm{CH}$, Kang CW, Zanesi N, Epling-Burnette PK, Sotomayor EM, Croce CM, Del Valle JR, Hu CC. Overexpression of TCL1 activates the endoplasmic reticulum stress response: a novel mechanism of leukemic progression in mice. Blood. 2012; 120:1027-1038.

36. Samali A, Fitzgerald U, Deegan S, Gupta S. Methods for monitoring endoplasmic reticulum stress and the unfolded protein response. Int J Cell Biol. 2010; 2010:830307.

37. Papandreou I, Denko NC, Olson M, Van Melckebeke H, Lust S, Tam A, Solow-Cordero DE, Bouley DM, Offner F, Niwa M, Koong AC. Identification of an Ire1alpha endonuclease specific inhibitor with cytotoxic activity against human multiple myeloma. Blood. 2011; 117:1311-1314.

38. Blum W, Schwind S, Tarighat SS, Geyer S, Eisfeld AK, Whitman S, Walker A, Klisovic R, Byrd JC, Santhanam R, Wang H, Curfman JP, Devine SM, Jacob S, Garr C, Kefauver C, et al. Clinical and pharmacodynamic activity of bortezomib and decitabine in acute myeloid leukemia. Blood. 2012; 119:6025-6031.

39. Urano F, Wang X, Bertolotti A, Zhang Y, Chung P, Harding HP, Ron D. Coupling of stress in the ER to activation of JNK protein kinases by transmembrane protein kinase IRE1. Science. 2000; 287:664-666.

40. Wang M, Kaufman RJ. The impact of the endoplasmic reticulum protein-folding environment on cancer development. Nature reviews Cancer. 2014; 14:581-597.

41. Vandewynckel YP, Laukens D, Geerts A, Bogaerts E, Paridaens A, Verhelst X, Janssens S, Heindryckx F, Van Vlierberghe H. The paradox of the unfolded protein response in cancer. Anticancer research. 2013; 33:4683-4694.

42. Paramore A, Frantz S. Bortezomib. Nat Rev Drug Discov. 2003; 2:611-612.

43. Obeng EA, Carlson LM, Gutman DM, Harrington WJ, Jr., Lee KP, Boise LH. Proteasome inhibitors induce a terminal unfolded protein response in multiple myeloma cells. Blood. 2006; 107:4907-4916.

44. Nawrocki ST, Carew JS, Dunner K, Jr., Boise LH, Chiao PJ, Huang P, Abbruzzese JL, McConkey DJ. Bortezomib inhibits PKR-like endoplasmic reticulum (ER) kinase and induces apoptosis via ER stress in human pancreatic cancer cells. Cancer Res. 2005; 65:11510-11519.

45. Lee AH, Iwakoshi NN, Anderson KC, Glimcher LH. Proteasome inhibitors disrupt the unfolded protein response in myeloma cells. Proc Natl Acad Sci U S A. 2003; 100:9946-9951.
46. Sanz MA, Fenaux P, Lo Coco F. Arsenic trioxide in the treatment of acute promyelocytic leukemia. A review of current evidence. Haematologica. 2005; 90:1231-1235.

47. Chiu HW, Tseng YC, Hsu YH, Lin YF, Foo NP, Guo HR, Wang YJ. Arsenic trioxide induces programmed cell death through stimulation of ER stress and inhibition of the ubiquitin-proteasome system in human sarcoma cells. Cancer letters. 2015; 356:762-772.

48. Chen J, Wei H, Xie B, Wang B, Cheng J, Cheng J. Endoplasmic reticulum stress contributes to arsenic trioxide-induced apoptosis in drug-sensitive and -resistant leukemia cells. Leukemia research. 2012; 36:1526-1535.

49. Lauricella M, Emanuele S, D'Anneo A, Calvaruso G, Vassallo B, Carlisi D, Portanova P, Vento R, Tesoriere G. JNK and AP-1 mediate apoptosis induced by bortezomib in HepG2 cells via FasL/caspase-8 and mitochondriadependent pathways. Apoptosis. 2006; 11:607-625.

50. Mann KK, Padovani AM, Guo Q, Colosimo AL, Lee HY, Kurie JM, Miller WH, Jr. Arsenic trioxide inhibits nuclear receptor function via SEK1/JNK-mediated RXRalpha phosphorylation. J Clin Invest. 2005; 115:2924-2933.

51. Hetz C, Chevet E, Harding HP. Targeting the unfolded protein response in disease. Nat Rev Drug Discov. 12:703-719.

52. Jones RL, Kim ES, Nava-Parada P, Alam S, Johnson FM, Stephens AW, Simantov R, Poondru S, Gedrich R, Lippman SM, Kaye SB, Carden CP. Phase I Study of Intermittent Oral Dosing of the Insulin-like Growth Factor-1 and Insulin Receptors Inhibitor OSI-906 in Patients With Advanced Solid Tumors. Clinical cancer research. 2015; 21:693-700.

53. Hosoi T, Ozawa K. Endoplasmic reticulum stress in disease: mechanisms and therapeutic opportunities. Clin Sci (Lond). 2010; 118:19-29.

54. Malhotra JD, Kaufman RJ. Endoplasmic reticulum stress and oxidative stress: a vicious cycle or a double-edged sword? Antioxid Redox Signal. 2007; 9:2277-2293.

55. Mimura N, Fulciniti M, Gorgun G, Tai YT, Cirstea D, Santo L, Hu Y, Fabre C, Minami J, Ohguchi H, Kiziltepe T, Ikeda H, Kawano Y, French M, Blumenthal M, Tam V, et al. Blockade of XBP1 splicing by inhibition of IRE1alpha is a promising therapeutic option in multiple myeloma. Blood. 2012; 119:5772-5781.

56. Ri M, Tashiro E, Oikawa D, Shinjo S, Tokuda M, Yokouchi Y, Narita T, Masaki A, Ito A, Ding J, Kusumoto S, Ishida T, Komatsu H, Shiotsu Y, Ueda R, Iwawaki T, et al. Identification of Toyocamycin, an agent cytotoxic for multiple myeloma cells, as a potent inhibitor of ER stressinduced XBP1 mRNA splicing. Blood Cancer J. 2012; 2:e79.

57. Chen X, Iliopoulos D, Zhang Q, Tang Q, Greenblatt MB, Hatziapostolou M, Lim E, Tam WL, Ni M, Chen Y, Mai J, Shen H, Hu DZ, Adoro S, Hu B, Song M, et al. XBP1 promotes triple-negative breast cancer by controlling the HIF1alpha pathway. Nature. 2014; 508:103-107. 
58. Leung-Hagesteijn C, Erdmann N, Cheung G, Keats JJ, Stewart AK, Reece DE, Chung KC, Tiedemann RE. Xbp1s-negative tumor B cells and pre-plasmablasts mediate therapeutic proteasome inhibitor resistance in multiple myeloma. Cancer cell. 2013; 24:289-304.

59. Tohmonda $T$, Yoda $M$, Iwawaki $T$, Matsumoto $M$, Nakamura M, Mikoshiba K, Toyama Y, Horiuchi K. IRE1alpha/XBP1-mediated branch of the unfolded protein response regulates osteoclastogenesis. The Journal of clinical investigation. 2015; 125:3269-3279.

60. Kharabi Masouleh B, Geng H, Hurtz C, Chan LN, Logan AC, Chang MS, Huang C, Swaminathan S, Sun H, Paietta E, Melnick AM, Koeffler P, Muschen M. Mechanistic rationale for targeting the unfolded protein response in pre-B acute lymphoblastic leukemia. Proceedings of the National Academy of Sciences of the United States of America. 2014; 111:E2219-2228.

61. Schardt JA, Weber D, Eyholzer M, Mueller BU, Pabst T. Activation of the unfolded protein response is associated with favorable prognosis in acute myeloid leukemia. Clinical cancer research. 2009; 15:3834-3841.

62. Yoshida H, Matsui T, Yamamoto A, Okada T, Mori $\mathrm{K}$. XBP1 mRNA is induced by ATF6 and spliced by IRE1 in response to ER stress to produce a highly active transcription factor. Cell. 2001; 107:881-891.

63. Plongthongkum N, Kullawong N, Panyim S, Tirasophon W. Ire1 regulated XBP1 mRNA splicing is essential for the unfolded protein response (UPR) in Drosophila melanogaster. Biochemical and biophysical research communications. 2007; 354:789-794.

64. Tam AB, Koong AC, Niwa M. Ire1 has distinct catalytic mechanisms for XBP1/HAC1 splicing and RIDD. Cell reports. 2014; 9:850-858.

65. Uemura A, Oku M, Mori K, Yoshida H. Unconventional splicing of XBP1 mRNA occurs in the cytoplasm during the mammalian unfolded protein response. Journal of cell science. 2009; 122:2877-2886.

66. Oikawa D, Tokuda M, Hosoda A, Iwawaki T. Identification of a consensus element recognized and cleaved by IRE1 alpha. Nucleic Acids Res. 2010; 38:6265-6273.

67. Hermeking $H$. The miR-34 family in cancer and apoptosis. Cell Death Differ. 17:193-199.

68. Ji Q, Hao X, Meng Y, Zhang M, Desano J, Fan D, Xu L. Restoration of tumor suppressor miR-34 inhibits human p53-mutant gastric cancer tumorspheres. BMC Cancer. 2008; 8:266.

69. Yin D, Ogawa S, Kawamata N, Leiter A, Ham M, Li D, Doan NB, Said JW, Black KL, Phillip Koeffler H. miR34a functions as a tumor suppressor modulating EGFR in glioblastoma multiforme. Oncogene. 32:1155-1163.

70. Yamakuchi M, Lowenstein CJ. MiR-34, SIRT1 and p53: the feedback loop. Cell Cycle. 2009; 8:712-715.

71. Hermeking $\mathrm{H}$. The miR-34 family in cancer and apoptosis. Cell Death Differ. 2010; 17:193-199.
72. Chen F, Hu SJ. Effect of microRNA-34a in cell cycle, differentiation, and apoptosis: a review. J Biochem Mol Toxicol. 2012; 26:79-86.

73. Kouroukis TC, Baldassarre FG, Haynes AE, Imrie K, Reece DE, Cheung MC. Bortezomib in multiple myeloma: systematic review and clinical considerations. Current oncology. 2014; 21:e573-603.

74. Robak T, Huang H, Jin J, Zhu J, Liu T, Samoilova O, Pylypenko H, Verhoef G, Siritanaratkul N, Osmanov E, Alexeeva J, Pereira J, Drach J, Mayer J, Hong X, Okamoto $\mathrm{R}$, et al. Bortezomib-based therapy for newly diagnosed mantle-cell lymphoma. The New England journal of medicine. 2015; 372:944-953.

75. Liu S, Liu Z, Xie Z, Pang J, Yu J, Lehmann E, Huynh L, Vukosavljevic T, Takeki M, Klisovic RB, Baiocchi RA, Blum W, Porcu P, Garzon R, Byrd JC, Perrotti D, et al. Bortezomib induces DNA hypomethylation and silenced gene transcription by interfering with $\mathrm{Sp} 1 / \mathrm{NF}-\mathrm{kappaB}$ dependent DNA methyltransferase activity in acute myeloid leukemia. Blood. 2008; 111:2364-2373.

76. Liu S, Wu LC, Pang J, Santhanam R, Schwind S, Wu YZ, Hickey CJ, Yu J, Becker H, Maharry K, Radmacher MD, Li C, Whitman SP, Mishra A, Stauffer N, Eiring AM, et al. Sp1/NFkappaB/HDAC/miR-29b regulatory network in KIT-driven myeloid leukemia. Cancer cell. 2010; 17:333-347.

77. Attar EC, De Angelo DJ, Supko JG, D’Amato F, Zahrieh D, Sirulnik A, Wadleigh M, Ballen KK, McAfee S, Miller KB, Levine J, Galinsky I, Trehu EG, Schenkein D, Neuberg $\mathrm{D}$, Stone RM, et al. Phase I and pharmacokinetic study of bortezomib in combination with idarubicin and cytarabine in patients with acute myelogenous leukemia. Clinical cancer research. 2008; 14:1446-1454.

78. Orlowski RZ, Voorhees PM, Garcia RA, Hall MD, Kudrik FJ, Allred T, Johri AR, Jones PE, Ivanova A, Van Deventer HW, Gabriel DA, Shea TC, Mitchell BS, Adams J, Esseltine DL, Trehu EG, et al. Phase 1 trial of the proteasome inhibitor bortezomib and pegylated liposomal doxorubicin in patients with advanced hematologic malignancies. Blood. 2005; 105:3058-3065.

79. Lo-Coco F, Avvisati G, Vignetti M, Thiede C, Orlando SM, Iacobelli S, Ferrara F, Fazi P, Cicconi L, Di Bona E, Specchia G, Sica S, Divona M, Levis A, Fiedler W, Cerqui E, et al. Retinoic acid and arsenic trioxide for acute promyelocytic leukemia. N Engl J Med. 369:111-121.

80. Zhang TD, Chen GQ, Wang ZG, Wang ZY, Chen SJ, Chen $Z$. Arsenic trioxide, a therapeutic agent for APL. Oncogene. 2001; 20:7146-7153.

81. Yang X, An L, Li X. Arsenic trioxide induced endoplasmic reticulum stress in laryngeal squamous cell line Hep-2 cells. Auris Nasus Larynx. 41:81-83.

82. Weng CY, Chiou SY, Wang L, Kou MC, Wang YJ, Wu MJ. Arsenic trioxide induces unfolded protein response in vascular endothelial cells. Arch Toxicol. 2014; 88:213-226. 
83. Douer D, Tallman MS. Arsenic trioxide: new clinical experience with an old medication in hematologic malignancies. Journal of clinical oncology. 2005; 23:2396-2410.

84. Andersson A, Ritz C, Lindgren D, Eden P, Lassen C, Heldrup J, Olofsson T, Rade J, Fontes M, PorwitMacdonald A, Behrendtz M, Hoglund M, Johansson B, Fioretos T. Microarray-based classification of a consecutive series of 121 childhood acute leukemias: prediction of leukemic and genetic subtype as well as of minimal residual disease status. Leukemia. 2007; 21:1198-1203.

85. Haferlach T, Kohlmann A, Wieczorek L, Basso G, Kronnie GT, Bene MC, De Vos J, Hernandez JM, Hofmann WK, Mills KI, Gilkes A, Chiaretti S, Shurtleff SA, Kipps TJ, Rassenti LZ, Yeoh AE, et al. Clinical utility of microarraybased gene expression profiling in the diagnosis and subclassification of leukemia: report from the International
Microarray Innovations in Leukemia Study Group. J Clin Oncol. 28:2529-2537.

86. Stegmaier K, Ross KN, Colavito SA, O’Malley S, Stockwell BR, Golub TR. Gene expression-based highthroughput screening(GE-HTS) and application to leukemia differentiation. Nat Genet. 2004; 36:257-263.

87. Wang YF, Deng SH, Wu T, Xu Y, Zou DH, Wang Y, Zhao YZ, Qiu LG. Outcome of bortezomib plus chemotherapy with or without stem cell transplantation for treatment of multiple myeloma. [Article in Chinese]. Zhonghua xue ye xue za zhi. 2008; 29:397-400.

88. Valk PJ, Verhaak RG, Beijen MA, Erpelinck CA, Barjesteh van Waalwijk van Doorn-Khosrovani S, Boer JM, Beverloo HB, Moorhouse MJ, van der Spek PJ, Lowenberg B, Delwel R. Prognostically useful gene-expression profiles in acute myeloid leukemia. N Engl J Med. 2004; 350:1617-1628. 